\title{
Study of the spectroscopic characteristics of methyl (ligand) cobaloximes and their antibacterial activity
}

\author{
N NAVANEETHA, ${ }^{a}$ P A NAGARJUN ${ }^{\mathrm{b}}$ and S SATYANARAYANA ${ }^{\mathrm{a}, *}$ \\ ${ }^{a}$ Department of Chemistry, and \\ ${ }^{\mathrm{b}}$ Department of Microbiology, Osmania University, Hyderabad 500007 \\ e-mail: ssnsirasani@yahoo.com
}

MS received 12 June 2006; revised 25 January 2007

\begin{abstract}
Spectroscopic characterization (IR, NMR and electronic spectra) of methyl (ligand) cobaloxime was done, where ligand = pyrazole, dimethyl pyrazole, alanine and alanine methyl ester. The frequency changes in the IR spectra and shifts in the NMR were explained on the basis of basicity of the ligand, steric hindrance, HSAB principle and $d \pi-p \pi$ back-bonding from metal to ligand. Alanine and alanine methyl ester form more stable complexes than pyrazole and dimethyl pyrazole. Based on their IR and ${ }^{1} \mathrm{H}$ NMR spectra it is inferred that pyrazole and dimethylpyrazole bind to Co (III) via N-2 ring nitrogen, i.e. monodentate coordination.
\end{abstract}

Keywords. Cobaloximes; spectroscopic characterization; monodentate coordination.

\section{Introduction}

Discoveries on the structure and models of vitamin $\mathrm{B}_{12}{ }^{1,2}$ are assessed in the light of the advances in structural and spectroscopic methodologies. It is well known that organocobaloximes, classical models for coenzyme $\mathrm{B}_{12}$ represented as $\mathrm{RCo}(\mathrm{DH})_{2} \mathrm{~L}(\mathbf{1}$, $\mathrm{DH}=$ mono anion of dimethyl glyoxime, $\mathrm{R}=$ alkyl,

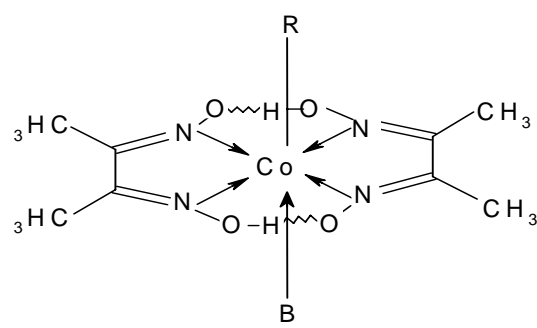

Methyl(ligand)cobaloxime (1)

$\mathrm{B}=\mathrm{Py}, \mathrm{DMPy}$, Ala and AME

$\mathrm{L}=$ neutral Lewis base) have been studied and reviewed in the last three decades ${ }^{3}$ due to their use as catalysts $^{4}$ and as templates in organic synthesis. ${ }^{5-13}$ However, the main interest still lies in their role as models of vitamin $B_{12}$, however, several additional structures have been reported including that of methylcobalamin $^{14,15}(\mathrm{MeCbl})$, which catalyses the

*For correspondence conversion of homocystein to methionine ${ }^{16,17}$ and ribonucleotide reductases. ${ }^{18-20}$

In the above reactions the key step is believed to be the homolytic cleavage of the $\mathrm{Co}-\mathrm{C}$ bond, ${ }^{21}$ which arises from the conformational changes in the enzyme which occurs upon substrate binding leading to a sterically strained adenosyl group. Spectroscopic studies on the model complexes help in establishing the basic relationship between structure and chemical properties. Kofod et $a l^{22}$, characterized cobalt (III) compounds with classical ligands by spectroscopic techniques. Bhoopal ${ }^{23}$ reported the equilibrium constants for the $\mathrm{pH}$-dependent axial ligation of $\mathrm{RCo}(\mathrm{DH})_{2} \mathrm{~L}$, where $\mathrm{R}=\mathrm{CH}_{3}, \mathrm{C}_{2} \mathrm{H}_{5}$ and $\mathrm{L}=\mathrm{Py}$, $4 \mathrm{Me}-\mathrm{Py}, 4 \mathrm{Eth}-\mathrm{Py} \& 4 \mathrm{NH}_{2} \mathrm{Py}$.

The systematic analysis of the structure-property relationship has furnished useful indications concerning the $\mathrm{Co}-\mathrm{C}$ bond homolysis mechanism in the $\mathrm{B}_{12}$ coenzyme. Canpolat et $a l^{24}$ reported that vicdioxime complexes of cobalt (III) complexes were the most active and may be promising for the development of new antibiotics.

\section{Materials and methods}

\subsection{Preparation of $\mathrm{CH}_{3} \mathrm{Co}(\mathrm{DH})_{2} \mathrm{~L}$}

$\mathrm{CH}_{3} \mathrm{Co}(\mathrm{DH})_{2} \mathrm{OH}_{2}$ was prepared by the procedure of Brown et $a l^{25}$. All manipulations were performed 
Table 1. Antimicrobial activity of the Co complexes at $20 \mu \mathrm{g} / \mathrm{ml}^{*}$.

\begin{tabular}{lrccc}
\hline & \multicolumn{5}{c}{ Bacterial species } \\
\cline { 2 - 5 } Complex & E. coli & K. pneumoniae & S. aureus & B. aureus \\
\hline $\mathrm{CH}_{3} \mathrm{Co}(\mathrm{DH})_{2} \mathrm{H}_{2} \mathrm{O}$ & 10 & 6 & 7 & 5 \\
$\mathrm{CH}_{3} \mathrm{Co}(\mathrm{DH})_{2} \mathrm{Ala}$ & 8 & 7 & 5 & 5 \\
$\mathrm{CH}_{3} \mathrm{Co}(\mathrm{DH})_{2} \mathrm{AME}$ & 8 & 8 & 9 & - \\
$\mathrm{CH}_{3} \mathrm{Co}(\mathrm{DH})_{2} \mathrm{Py}$ & 10 & 5 & - & - \\
$\mathrm{CH}_{3} \mathrm{Co}(\mathrm{DH})_{2} \mathrm{DMPy}$ & 5 & - & 11 & -14 \\
Tetracycline & \multicolumn{5}{c}{$6-8$} \\
Bacitracin & \multicolumn{5}{c}{ - } & 5 & - & \\
\hline
\end{tabular}

*Values of zone of inhibition (mm, including the diameter of the disc)

Table 2. ${ }^{1} \mathrm{H}$ NMR and electronic spectral data of $\mathrm{CH}_{3} \mathrm{Co}(\mathrm{DH})_{2} \mathrm{~L}^{*}$.

\begin{tabular}{|c|c|c|c|c|c|c|c|c|c|c|}
\hline \multirow[b]{2}{*}{ Complex } & \multirow[b]{2}{*}{$\left(\mathrm{CH}_{3}\right)_{4}^{\#}$} & \multirow[b]{2}{*}{$\begin{array}{c}\mathrm{CH}_{3^{-}} \\
\mathrm{Co}\end{array}$} & \multirow[b]{2}{*}{ C-H-4 } & \multirow[b]{2}{*}{$\begin{array}{l}\mathrm{H}-3 / \\
\mathrm{Me}-3\end{array}$} & \multirow[b]{2}{*}{$\begin{array}{l}\mathrm{H}-5 / \\
\mathrm{Me}-5\end{array}$} & \multirow[b]{2}{*}{$\begin{array}{l}-\mathrm{NH}_{2} / \\
-\mathrm{NH}\end{array}$} & \multirow{2}{*}{$\begin{array}{l}-\mathrm{CH} / \\
-\mathrm{CH}_{3}{ }^{\oplus}\end{array}$} & \multicolumn{3}{|c|}{ UV-Visible data } \\
\hline & & & & & & & & Peak I & Peak 2 & Peak 3 \\
\hline $\mathrm{CH}_{3} \mathrm{Co}(\mathrm{DH})_{2} \mathrm{H}_{2} \mathrm{O}$ & $2 \cdot 10$ & $0 \cdot 5$ & - & - & - & - & - & 24183.8 & $27700 \cdot 8$ & $36024 \cdot 5$ \\
\hline $\mathrm{CH}_{3} \mathrm{Co}(\mathrm{DH})_{2} \mathrm{Py}$ & $2 \cdot 10$ & $0 \cdot 6$ & $6 \cdot 30$ & $7 \cdot 60(d)$ & $7 \cdot 40(d)$ & $11 \cdot 80$ & - & $22805 \cdot 0$ & $27137 \cdot 0$ & $36563 \cdot 1$ \\
\hline $\mathrm{CH}_{3} \mathrm{Co}(\mathrm{DH})_{2} \mathrm{DMPy}$ & $2 \cdot 10$ & $0 \cdot 6$ & $5 \cdot 80(d)$ & $2 \cdot 5$ & $2 \cdot 3$ & $10 \cdot 6$ & - & $22805 \cdot 0$ & $26773 \cdot 8$ & $36563 \cdot 1$ \\
\hline $\mathrm{CH}_{3} \mathrm{Co}(\mathrm{DH})_{2} \mathrm{Ala}$ & $2 \cdot 20$ & 0.5 & $3 \cdot 20$ & - & - & $3 \cdot 8$ & $1 \cdot 2$ & $22805 \cdot 0$ & $26595 \cdot 7$ & $36231 \cdot 9$ \\
\hline $\mathrm{CH}_{3} \mathrm{Co}(\mathrm{DH})_{2} \mathrm{AME}$ & $2 \cdot 20$ & 0.5 & $3 \cdot 10$ & - & - & $0 \cdot 2$ & $0 \cdot 8$ & $22675 \cdot 7$ & $26246 \cdot 7$ & $37950 \cdot 0$ \\
\hline
\end{tabular}

${ }^{\$}$ In ppm relative to tetra methyl silane

$* \mathrm{~L}, \mathrm{Py}=$ pyrazole, DMPy $=$ dimethyl pyrazole, $\mathrm{Ala}=$ alanine, $\mathrm{AME}=$ alanine methylester

I $-\mathrm{CH} /-\mathrm{CH}_{3}$ of the ligand

under minimal illumination due to photolability of the organo cobalt bond. ${ }^{26}\left[\mathrm{CH}_{3} \mathrm{Co}(\mathrm{DH})_{2} \mathrm{~L}\right]$ complexes were isolated by mixing $1: 1$ ratio of $\mathrm{CH}_{3} \mathrm{Co}$ $(\mathrm{DH})_{2} \mathrm{OH}_{2}$ and the base ligand(L) in methanol. This mixture was heated at $40-50^{\circ} \mathrm{C}$ by constant stirring for 1-2 $\mathrm{h}$. Then the minimum amount of distilled water was added, the resulting precipitate of yellow powder was filtered, washed with distilled water, 95\% methanol and ether and dried in vacuo (yields were $70-80 \%) .{ }^{1} \mathrm{H}$ NMR spectra were recorded on Varian Gemini $200 \mathrm{MHz}$ NMR spectrometer. Samples were prepared by dissolving in $\mathrm{CDCl}_{3}$ and DMSO- $d_{6}$. Infrared spectra were obtained on a Perkin-Elmer FTIR-1605 spectrometer using $\mathrm{KBr}$ pellets.

The antimicrobial activities of the compounds were determined in vitro using different microorganisms by the standard disc diffusion method. ${ }^{27}$ The following bacteria were used: Escherichia coli (MTCC 1234), Klebsiella pneumoniae (MTCC 1234), Staphylococcus aureus (MTCC 1234) and Bacillus subtilis (MTCC 1234). Bacterial cultures were sub-cultured in nutrient broth medium and incubated at $37^{\circ} \mathrm{C}$ for $18 \mathrm{~h}$ and the logarithmic or ex- ponential phase was achieved. Filter paper discs of $4 \mathrm{~mm}$ size were prepared by using Whatmann filter paper no. 1, and on to each of these discs a $5 \mu \mathrm{l}$ of a solution of the complex in DMSO was added. At the end of the incubation period the zones of inhibition were measured (table 1).

\section{Results and discussion}

\subsection{Spectral analysis}

In this paper we report complexes of type $\mathrm{CH}_{3} \mathrm{Co}(\mathrm{DH})_{2} \mathrm{~L}$, where $\mathrm{L}=\mathrm{Py}$ (pyrazole), DMPy (dimethyl pyrazole), Ala (alanine) and AME (alanine methyl ester). Electronic data (table 2) of the $\mathrm{CH}_{3} \mathrm{Co}(\mathrm{DH})_{2} \mathrm{~L}$ complexes show the most intense band in the highest energy region $\left(\sim 36,000 \mathrm{~cm}^{-1}\right)$ have been assigned to Co (III) $\mathrm{d} \pi \rightarrow \pi^{*}(\mathrm{DH})$ MLCT transition of the equatorial ligand. The lowest energy band $\left(\sim 22,000 \mathrm{~cm}^{-1}\right)$ has been assigned to a $\mathrm{Co}-\mathrm{C}$ charge transfer, transition ${ }^{28}$ due to $\mathrm{R}^{-}$to Co (III) is a spin-allowed ${ }^{1} A_{1} g \rightarrow{ }^{1} T_{1} g$ transition, ${ }^{29}$ and this band disappears or is drastically decreased in alkyl (ligand) cobaloximes due to $\sigma$ donation by the ligand. The 
Table 3. IR data for the methyl (ligand) cobaloxime.

\begin{tabular}{|c|c|c|c|c|c|c|c|}
\hline \multirow[b]{2}{*}{ Complex } & \multicolumn{3}{|c|}{$\mathrm{DH}$} & \multirow[b]{2}{*}{$v(\mathrm{Co}-\mathrm{N})$} & \multirow[b]{2}{*}{$v(\mathrm{Co}-\mathrm{N})^{\#}$} & \multicolumn{2}{|c|}{$\mathrm{L}$} \\
\hline & $v\left(\mathrm{CH}_{3}\right)$ & $v(\mathrm{C}=\mathrm{N})$ & $\mathrm{N}(\mathrm{NO})$ & & & $v(\mathrm{C}=\mathrm{N})$ & $v(-\mathrm{N}-\mathrm{H})$ \\
\hline $\mathrm{CH}_{3} \mathrm{Co}(\mathrm{DH})_{2} \mathrm{H}_{2} \mathrm{O}$ & $1360 \cdot 8$ & $1557 \cdot 9$ & $1084 \cdot 6$ & $508 \cdot 8$ & - & - & - \\
\hline $\mathrm{CH}_{3} \mathrm{Co}(\mathrm{DH})_{2} \mathrm{Py}$ & $\begin{array}{l}1372 \cdot 5 \\
1455 \cdot 4\end{array}$ & $1556 \cdot 2$ & $\begin{array}{l}1082 \cdot 8 \\
1229 \cdot 0\end{array}$ & $513 \cdot 8$ & - & $\begin{array}{c}573 \cdot 4 \\
2357 \cdot 5\end{array}$ & $2907 \cdot 5$ \\
\hline $\mathrm{CH}_{3} \mathrm{Co}(\mathrm{DH})_{2} \mathrm{DMPy}$ & $\begin{array}{l}1381 \cdot 6 \\
1466 \cdot 3\end{array}$ & $1566 \cdot 6$ & $\begin{array}{l}1125 \cdot 7 \\
1232 \cdot 4\end{array}$ & $517 \cdot 2$ & - & $\begin{array}{c}614 \cdot 5 \\
2366 \cdot 9\end{array}$ & $3130 \cdot 8$ \\
\hline $\mathrm{CH}_{3} \mathrm{Co}(\mathrm{DH})_{2} \mathrm{Ala}$ & $\begin{array}{l}1372 \cdot 5 \\
1425 \cdot 4\end{array}$ & $1559 \cdot 2$ & $\begin{array}{l}1091 \cdot 7 \\
1234 \cdot 8\end{array}$ & $517 \cdot 6$ & $479 \cdot 3$ & - & $3280 \cdot 5$ \\
\hline $\mathrm{CH}_{3} \mathrm{Co}(\mathrm{DH})_{2} \mathrm{AME}$ & $\begin{array}{l}1371 \cdot 7 \\
1445 \cdot 8\end{array}$ & $1573 \cdot 9$ & $\begin{array}{l}1083 \cdot 9 \\
1230 \cdot 3\end{array}$ & $511 \cdot 6$ & $450 \cdot 0$ & - & $3108 \cdot 4$ \\
\hline
\end{tabular}

${ }^{\$}$ Recorded as $\mathrm{KBr}$ discs and values in $\mathrm{cm}^{-1}$

${ }^{*} \mathrm{~L}, \mathrm{Py}=$ pyrazole, DMPy $=$ dimethyl pyrazole, $\mathrm{Ala}=$ alanine and $\mathrm{AME}=$ alanine methyl ester

${ }^{\#}(\mathrm{Co}-\mathrm{N}), \mathrm{N}$ of ligand

Table 4 MIC* of chemotherapeutic agent.

\begin{tabular}{lc}
\hline Complex & MIC $(\mu \mathrm{g})$ \\
\hline $\mathrm{CH}_{3} \mathrm{Co}(\mathrm{DH})_{2} \mathrm{H}_{2} \mathrm{O}$ & 20 \\
$\mathrm{CH}_{3} \mathrm{Co}(\mathrm{DH})_{2} \mathrm{Ala}$ & 40 \\
$\mathrm{CH}_{3} \mathrm{Co}(\mathrm{DH})_{2} \mathrm{AME}$ & 20 \\
$\mathrm{CH}_{3} \mathrm{Co}(\mathrm{DH})_{2} \mathrm{Py}$ & 20 \\
$\mathrm{CH}_{3} \mathrm{Co}(\mathrm{DH})_{2} \mathrm{DMPy}$ & 80 \\
\hline
\end{tabular}

*Minimum inhibitory concentration in $\mu \mathrm{g} /$ disc

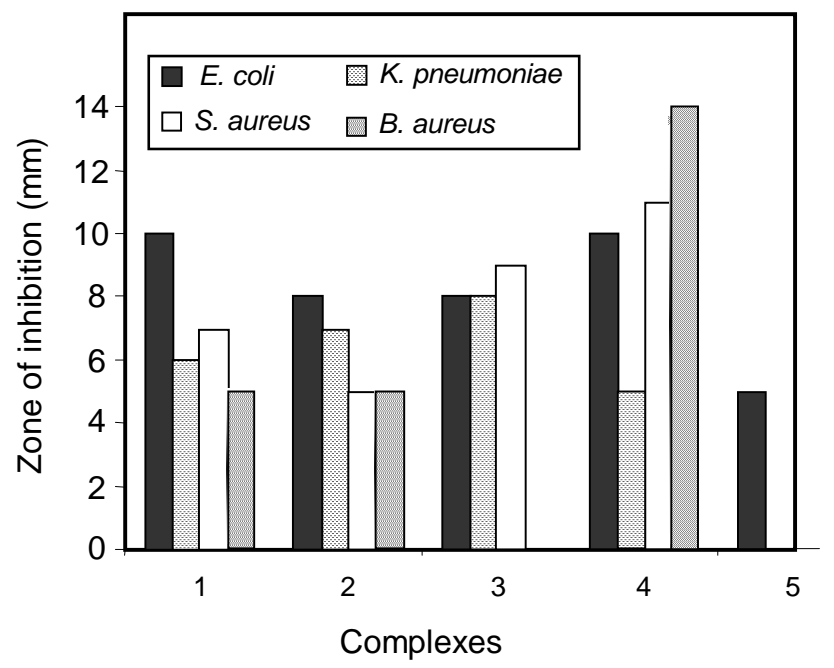

Figure 1. Bar graph showing the relative activity of the complexes.

${ }^{1} A_{1} g \rightarrow{ }^{1} T_{1} g$ band is masked by the intense CT bands. Bands occurring at $26,500 \mathrm{~cm}^{-1}$ are assigned to the $\mathrm{L} \rightarrow \mathrm{Co}$ (III), LMCT. The $\sigma \mathrm{DH} \rightarrow \sigma^{*} \mathrm{Co}$ (III) is masked by the intense short wavelength bands of alkyl (ligand) cobaloximes. ${ }^{30}$ The Co-C CT band shifts to shorter wavelengths with decreasing electron-donating ability of the axial base. ${ }^{31}$

Marzilli et $a l^{32}$, described the first application of near-IR excited Raman (near IR-FT Raman) spectroscopy to study photo-labile methyl cobaloxime. The disappearance of the peak at $3072 \mathrm{~cm}^{-1}$ and appearance of a new peak at $450 \mathrm{~cm}^{-1} v(\mathrm{Co}-\mathrm{N})$ indicates the formation of methyl(ligand)cobaloxime by replacing $\mathrm{H}_{2} \mathrm{O}$. The IR spectra of free ligands were compared with the IR spectra of their corresponding cobaloxime complexes in order to identify the diagnostic bands. For pyrazole and dimethyl pyrazole, monodentate coordination has been assigned through $\mathrm{N}-2$, based on their IR spectra (table 3 ).

However, the definite relationship between frequency shifts and consecutive order of axial ligands was observed as mentioned, i.e. $\mathrm{H}_{2} \mathrm{O}<$ pyrazole. In short, as the donating power of the base ligand increases, the $v(\mathrm{O}-\mathrm{H} \ldots \mathrm{O})$ at $\sim 1770 \mathrm{~cm}^{-1}$ and $v(\mathrm{C}=\mathrm{N})$ at $\sim 1570 \mathrm{~cm}^{-1}$ shifts to a lower wave number region, while $v(\mathrm{~N}-\mathrm{O})$ at $\sim 1230 \mathrm{~cm}^{-1}$ and $1085 \mathrm{~cm}^{-1}, v(\mathrm{Co}-\mathrm{N})$ at $\sim 510 \mathrm{~cm}^{-1}$ shift to higher one. These results can be interpreted as follows. The coordination of the more electron-donating base to Co atom causes increase in electron density in $\mathrm{Co}(\mathrm{III})$, which facilitates back-donation from $\mathrm{Co}(\mathrm{III})$ to the nitrogen atoms of dimethyl glyoximato ligands resulting in increase in electron densities in $\mathrm{C}=\mathrm{N}$ and $\mathrm{N}-\mathrm{O}$ bonds. The increase in electron density in $\mathrm{N}-\mathrm{O}$ bonds leads to the stronger hydrogen bridges of $\mathrm{O}-\mathrm{H} . . . \mathrm{O}$ and higher frequency shifts of $\mathrm{N}-\mathrm{O}$ stretching vibrations. The facilitated back-donation from the cobalt to nitrogen atoms of dimethyl glyoxime lowers the $\mathrm{C}=\mathrm{N}$ stretching frequency. 
Table.5. Formation constants for the axial ligation of $\mathrm{CH}_{3} \mathrm{Co}(\mathrm{DH})_{2} \mathrm{OH}_{2}$ by bioactive ligands at $25^{\circ} \mathrm{C}$ in aqueous solution, ionic strength $1.0 \mathrm{M}(\mathrm{KCl})$.

\begin{tabular}{|c|c|c|c|c|}
\hline \multirow[b]{2}{*}{$\mathrm{pH}$} & \multicolumn{4}{|c|}{$\mathrm{R}=\mathrm{CH}_{3}$} \\
\hline & $\log K_{\text {app }}$ & $\log K_{\text {app }}$ & $\log K_{\text {app }}$ & $\log K_{\mathrm{app}}$ \\
\hline $1 \cdot 0$ & 0.7314 & - & - & - \\
\hline $1 \cdot 5$ & $1 \cdot 2060$ & - & - & - \\
\hline $2 \cdot 0$ & $1 \cdot 6326$ & - & - & - \\
\hline $2 \cdot 5$ & 1.9587 & 0.3363 & - & - \\
\hline $3 \cdot 0$ & $2 \cdot 1483$ & $0 \cdot 8201$ & - & - \\
\hline $3 \cdot 5$ & $2 \cdot 2308$ & $1 \cdot 2740$ & - & - \\
\hline $4 \cdot 0$ & $2 \cdot 2605$ & $1 \cdot 6535$ & - & - \\
\hline $4 \cdot 5$ & $2 \cdot 2703$ & 1.9064 & - & - \\
\hline $5 \cdot 0$ & - & $2 \cdot 0312$ & - & - \\
\hline $5 \cdot 5$ & - & $2 \cdot 0768$ & - & - \\
\hline $6 \cdot 0$ & - & $2 \cdot 0956$ & - & - \\
\hline $6 \cdot 5$ & - & - & - & $1 \cdot 4022$ \\
\hline $7 \cdot 0$ & - & - & - & $1 \cdot 8883$ \\
\hline $7 \cdot 5$ & - & - & - & $2 \cdot 3454$ \\
\hline $8 \cdot 0$ & - & - & $1 \cdot 7678$ & $2 \cdot 7310$ \\
\hline $8 \cdot 5$ & - & - & $2 \cdot 2558$ & $3 \cdot 0759$ \\
\hline $9 \cdot 0$ & - & - & $2 \cdot 7164$ & $3 \cdot 1234$ \\
\hline $9 \cdot 5$ & - & - & $3 \cdot 1097$ & $3 \cdot 1748$ \\
\hline $10 \cdot 0$ & - & - & $3 \cdot 3822$ & $3 \cdot 1924$ \\
\hline $10 \cdot 5$ & - & - & $3 \cdot 5535$ & - \\
\hline $11 \cdot 0$ & - & - & $3 \cdot 5895$ & - \\
\hline $11 \cdot 5$ & - & - & $3 \cdot 5983$ & - \\
\hline$K_{\mathrm{eq}}\left(\mathrm{M}^{-1}\right)$ & $K_{\mathrm{Py}}=1884$ & $K_{\mathrm{DMPy}}=127 \cdot 01$ & $K_{\mathrm{Ala}}=4041 \cdot 3$ & $K_{\mathrm{AME}}=1587.97$ \\
\hline
\end{tabular}

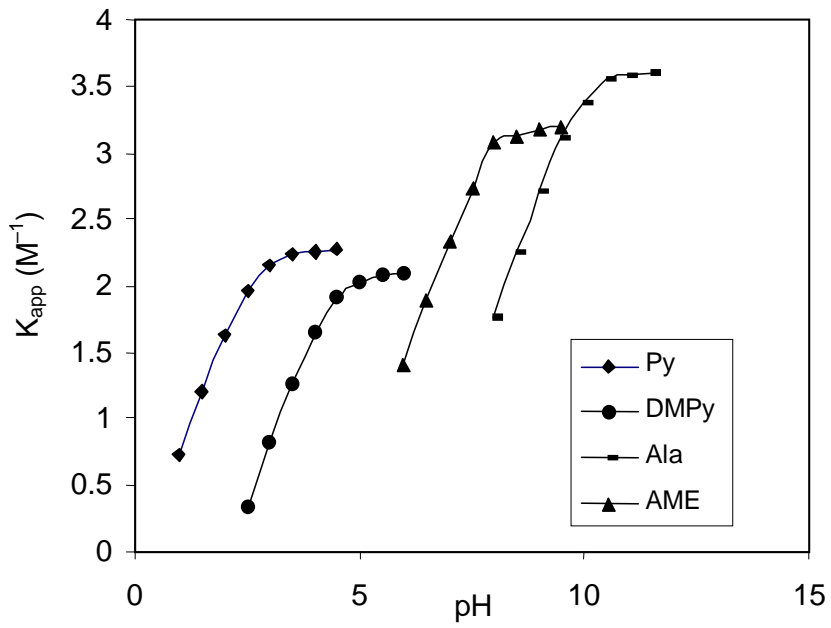

Figure 2. Dependence of apparent equilibrium constants $\left(\log K_{\text {app }}\right)$ on $\mathrm{pH}$ for the axial ligation of $\mathrm{CH}_{3} \mathrm{Co}$ $(\mathrm{DH})_{2} \mathrm{OH}_{2}$ by Py, DMPy, Ala and AME at $25^{\circ} \mathrm{C}$ in aqueous solution, ionic strength $1.0 \mathrm{M}(\mathrm{KCl})$.

A strong electron-withdrawing ligand in the sixth position causes stronger interaction between the central metal and the fifth ligand in the trans position which could be caused by decrease in the cobalt $\rightarrow \mathrm{N}$ (base) bond length. Donation of electrons from base to cobalt atom is thus facilitated which results in stronger back-donation from cobalt to the equatorial nitrogen atoms and hence an increase of electron density in the equatorial bis(dimethyl glyoximato) moiety. As the electron-donating power of ligand increases, the binding constant $\left(K_{\text {eq }}\right)$ increases in the complexes. Figure 2 shows the $\mathrm{pH}$ dependence of the $K_{\mathrm{eq}}$. Formation constants data for the substitution reaction of methyl(aquo)cobaloxime are given in table 5. This is also supported by our binding studies $^{33}$ of iodomethyl(aquo)cobaloxime and the formation constants $\left(K_{\mathrm{eq}}\right)$ follows the order

$$
\text { Ala }>\text { AME }>\text { Py }>\text { DMPy } .
$$

The ${ }^{1} \mathrm{H}$ NMR spectrum of $\mathrm{CH}_{3} \mathrm{Co}(\mathrm{DH})_{2} \mathrm{H}_{2} \mathrm{O}$ contain well resolved absorptions corresponding to the axial methyl and equatorial methyl groups of dimethyl glyoxime (DH). The sharp signals at 0.5 and $2.20 \mathrm{ppm}$ integrating in the ratio $1: 4$ have been assigned to the trans $\mathrm{CH}_{3}$ group (alkyl group trans to $\mathrm{Co}$ ) and 
the four $\mathrm{CH}_{3}$ groups (of DMG) respectively. The ${ }^{1} \mathrm{H}$ NMR data (table 2) of methyl(ligand)cobaloxime show that cis and trans methyl groups are distinctly different.

In the free ligand (Py and DMPy) the $\mathrm{H}_{3} / \mathrm{CH}_{3}$ and $\mathrm{H}_{5} / \mathrm{CH}_{5}$ are averaged by rapid proton exchange and all the hydrogens are shifted upfield upon coordination. Pyrazole $\mathrm{H}_{4}$ signal is at $6.1 \mathrm{ppm}$ and it is slightly shifted upfield compared to the free ligand position because of the loss in aromaticity due to the withdrawal of electron density from N-2 to Co (III) and as a result ring protons experience a higher shielding effect. When pyrazole coordinates to Co (III), the C-3 and C-5 signals separates and gives two signals at 7.71 and $7.22 \mathrm{ppm}$ respectively.

\subsection{Antibacterial activity}

From the zone of inhibition (table 1) test it has been found that when the agar plates were supplemented with antibiotics, e.g. tetracycline and bacitracin, the inhibited area was $10-14 \mathrm{~mm}$ and $6-8 \mathrm{~mm}$ respectively. When the same agar plates were supplemented with our complexes, it has been observed that Klebsiella pneumoniae and Staphylococcus aureus were sensitive to the complex as for tetracycline. The next species Bacillus subtilis lies in between and Escherichia coli is the least affected. In general, it is found that all the complexes exhibit inhibition against both gram-positive and gram-negative bacteria.

Among all the complexes tested, $\mathrm{CH}_{3} \mathrm{Co}(\mathrm{DH})_{2}$ (DMPy) is effective only with Escherichia coli. When compared to the antibiotic bacitracin, the cobaloximes were found to be more effective, and were less active than tetracycline. Compounds such as $\mathrm{CH}_{3} \mathrm{Co}(\mathrm{DH})_{2}\left(\mathrm{H}_{2} \mathrm{O}\right)$ and $\mathrm{CH}_{3} \mathrm{Co}(\mathrm{DH})_{2}(\mathrm{Py})$ were found to show activity equivalent to the antibiotic tetracycline against certain bacteria.

Initially at higher concentrations, the activity was determined and subsequently all these were further tested to determine the minimum growth inhibitory concentration for the growth of E. coli (table 4). The control MIC was $100 \mu \mathrm{g}$. From the above results it is seen that these complexes possess antibacterial activity.

\section{Conclusions}

Methyl(aquo)cobaloxime reacts with Py, DMPy, Ala, AME and forms stable methyl(ligand)cobal- oxime whose stability has been explained on the basis of basicity of the ligand, steric hindrance, HSAB principle and $d \pi-p \pi$ back-bonding. Py and DMPy bind to Co (III) through the N-2 of the ring and Ala and AME through $\mathrm{N}$ of $\mathrm{NH}_{2}$ group. The reported cobaloximes possess a broad range antibiotic activity and show promise for the development of new antibiotics.

\section{References}

1. Hodgkin D C, Lindsey J, Sparks R A, Trueblood K N and White J G 1962 Proc. R. Soc. A266 494

2. Brink-Shoemaker C, Cruickshank D W J, Hodgkin D C, Kamper M J and Pilling D 1964 Proc. R. Soc. A278 1

3. Bresciani-Pahor N, Forcolin M, Marzilli L G, Randaccio L, Summers M F and Toscano P J 1985 Coord. Chem. Rev. 631

4. Nemeth S and Simandi L 1982 J. Mol. Catal. 1287

5. Giese B 1986 Radicals in organic synthesis formation of carbon-carbon bond (eds) (Oxford: Pergamon)

6. Scheffold R, Rytez G and Walder L 1983 Transition metals in organic synthesis (ed.) R Scheffold (Chichester: Wiley) vol. 3

7. Ghosh A K and Chen Y 1995 Tetrahedron Lett. 505

8. Wright M and Welker M E 1996 J. Org. Chem. 61133

9. Gupta B D, Singh V, Qanungo K, Vijaikanth V and Sengar R S 1999 J. Organomet. Chem. 582279

10. Gupta B D, Dixit V and Das J 1999 J. Organomet. Chem. 57249

11. Brown T, Dronsfield A, Jablonski A and Wilkinson A S 1996 Tetrahedron Lett. 375413

12. Gill G B, Pattenden G and Raon G A 1996 Tetrahedron Lett. 379369

13. Gage J L and Branchaud B P 1997 Tetrahedron Lett. 407007

14. Halpern J 1985 Science 227869

15. Glusker J P $B_{12}$ (ed.) D Dolphin (New York: Wiley) vol 1, pp 23-106, vol 2

16. Mathews R G and Drummond J T 1990 Chem. Rev. 901275

17. Drennan C L, Dixon M M, Hoover D M, Jarret J T, Goulding C W, Mathews R G and Ludwig M L 1998 Vit. $B_{12} \& B_{12}$ proteins (eds) B Krautler, D Arigoni and B T Goldings (Weinheim: Wiley-VCH) p. 133

18. Stubbe J, Licht S, Gerfen G and Booker S 1998 Vit $B_{12}$ and $B_{12}$ proteins (eds) B Krautler, D Arigoni and B T Goldings (Weinheim: Wiley-VCH) p. 320, and ref. therein

19. Licht S, Booker S and Stubbe J 1999 Biochemistry 38 1221

20. Licht S, Gerfen G and Stubbe J 1996 Science 271477

21. Cregan A G, Brasch N E and Eldik R V 2001 Inorg. Chem. 401430

22. Kofod P, Harris P and Larsen S 1997 Inorg. Chem. 362258

23. Bhoopal M and Satyanarayana S 2004 J. Indian Chem. Soc. A43 1409 
24. Canpolat E and Kaya M 2004 Turk. J. Chem. 28235

25. Brown K L 1986 Organometallic syntheses (eds) R B King and $\mathrm{J}$ Eisch (Amsterdam: Elsevier) vol 3, p. 186

26. Brown K L and Kallen R G 1972 J. Am. Chem. Soc. 941894

27. Drew W L, Barry A L, O'Toole R and Sherris J C 1972 Appl. Environ. Microbiol. 24240

28. Lever A B P 1968 Inorganic electronic spectroscopy (Amsterdam: Elsevier)
29. Halpern J, Palmer R A and Blakley L M 1966 J. Am. Chem. Soc. 882897

30. Yamano Y, Masuda I and Shimura K 1972 Bull. Chem. Soc. Jpn. 441581

31. Radhakrishna Reddy M, Mohana Raju K and Hussain Reddy K 1996 Indian J. Chem. A35 677

32. Nie S, Marzilli L G and Yu N T 1989 J. Am. Chem. Soc. 1119256

33. Navaneetha $\mathrm{N}$ and Satyanarayana S 2005 Indian J. Chem. A44 1191 